\title{
Syrians and Business in Irbid City: Jordanian Stability and Refugees: A Qualitative Study
}

\author{
Khaled K. Alafi ${ }^{1} \&$ Moayyad Alfawaeer ${ }^{1}$ \\ ${ }^{1}$ Department of Management, Faculty of Finance and Business Administration, The World Islamic Sciences \& \\ Education University, Jordan \\ Correspondence: Khaled K. Alafi, Department of Management, Faculty of Finance and Business Administration, \\ The World Islamic Sciences \& Education University, P. O. Box 1101, Postal Code 11947, Amman, Jordan. \\ E-mail: allafykhaled99@yahoo.com
}

Received: February 1, 2014

Accepted: April 8, 2014

Online Published: May 22, 2014

doi:10.5539/ijbm.v9n6p115

URL: http://dx.doi.org/10.5539/ijbm.v9n6p115

\begin{abstract}
Aim: Against Jordan's historical and economic background, the question of the effects on business of Syrian refugees' fleeing the civil war and their demand for accommodation and business purchase in Irbid, a northern city, is investigated. The hope was to link these local social and economic problems and their effects to nationwide demands, more prevalent in the south, for socio-economic improvement for business opportunity and increased political freedom.
\end{abstract}

Methodology: Qualitative data from semi-structured interviews with 33 of 41 Irbid realtors

Results: Local dislocation affected the lower socio-economic group on limited incomes, depriving them of accommodation. Predominantly the rich Jordanian elite profited by increased investment and rental profit. Refugee Syrians comprised only $10 \%$ of the market. Some astute Syrian businessmen invested their wealth in Irbid, improving the general economy. Irbid commercial and retail business boomed with increased consumers. There was insufficient discontent evidenced with the political or economic situation to threaten the political status quo, according to realtors. The King is loved, and trusted to encourage more foreign investment. Realtors expected the real estate market to rise slightly with new demand, or stabilise; although locally limited-income Jordanians hope for assistance in the form of a government sector wage rise-unlikely with national economic woes.

Keywords: Arab Spring, Jordanian refugees, Syrian refugees, real estate, Jordanian economic situation, Irbid business, socio-economic problems

\section{Introduction}

\subsection{The Problem}

Jordan is a roughly 90000 sq. km. predominantly arid desert kingdom NW of Saudi Arabia, bounded by Israel and war-torn Iraq. It offers few natural resources (phosphates, potash and shale oil) with $2 \%$ arable land and limited water. However, it has offered peace and security to refugees from surrounding countries. The existence of this haven as a refuge for those escaping the violence of Syria since 2010 has brought economic problems to urban areas of Jordan closest to the Syrian border. All refugees need food, consumer products and accommodation. The latter needs place increased pressure on business premises, house and apartment supplies available, driving up rental and selling prices and reducing their availability for Jordanians as, it was hypothesised, wealthy Syrians snap up what is available.

This raises the key question of what are the consequences of the three-year Syrian civil war on the real estate market and business in Jordan? The aim of this research is to find the effects on the group of lower socio-economic Jordanians affected by new pressure on the housing and business premises market and if this downturn might further effect the underlying social, political and economic instability in Jordan (Khandelwal \& Roitman, 2013). The Arab Spring unrest started Dec. 2010 in Tunisia and spread over much of the autocratically governed and repressed North African and Middle Eastern Arab world from Jan. 2011 (O'Sullivan, Rey, \& Mendez, 2012). Protesters demanded "increased inclusion in economic and political life, better governance and strengthened civil liberties" (Masetti, Komer, Forster \& Friedman, 2013, p. 1). The research might clarify to 
some degree whether the general Jordanian aims driving the peaceful demonstrations in the south demanding constitutional reform, greater freedoms and improved economic conditions, might still be present in the north of Jordan.

\subsection{Importance}

Other than sparse government statistics, there has been no previous research done on this specific subject thus basic qualitative research was required to collect grounded data revealing in three dimensional from the issues as perceived by the local population via the most interested observers: the realtors involved. This forms a basis for further study of the problem as events unfold and provides data on an important present social problem such as the $300 \%$ increase in apartment rentals, according to local realtors.

This issue of accommodation for refugees is revealed by historical research with a brief background on Jordan of the past 50 years as a haven for refugees from surrounding countries. The recent Arab Spring demonstration demands for reform raises the question of and how these two historical elements might affect the future of Jordan. Although the north was not involved in the uprising, perceptions revealed by in-depth interviews of the points of view of uncommitted people and their reasons for these may reveal how their perspectives are shaped by and in turn shape their social, cultural and business contexts. Perceptions of Syrian neighbours might be greatly altered with this war (Maxwell, 2013).

In summary, the purpose of the research is to provide base data in exploring an original but important recent social and economic problem affecting Irbid Jordanians. The problem was caused by rich Syrian refugees fleeing the civil war and buying or renting accommodation in peaceful but poverty-stricken Jordan since 2011. It should help in understanding the effect of some refugees on a friendly neighbouring nation and give a fresh picture of the present situation from observers involved.

\subsection{Background Literature}

\subsubsection{Political Problems}

Since its inception as a small and weak nation by Churchill in 1921, quiet, peaceful Jordan became independent in 1946. The Hashemite kingdom has been vulnerable to the political changes in fortune of its Arab world neighbours and it has historically been the target of frequent incursions by refugees beginning after the 1948 Arab-Israeli War. The Palestinian population of the West Bank became part of Jordan and Palestinian numbers were twice the existing Jordanian population, so their influence on domestic politics was revolutionary (Susser, 2013). To govern the present population of about six and a half million Arabs, the hereditary king appoints the Prime minister and Cabinet although according to the latest amended constitution in 2012, there is an elected Chamber of Deputies (2013) with 23 parties represented (although boycotted by the powerful Islamic Action Front). Additionally there exist 36 political parties including the Muslim Brotherhood and 17 pressure groups listed by the CIA in 2013 (CIA, 2014). Lack of a genuine or unified political opposition gives the king and administration considerable freedom to act and control the economy. The general problems to be addressed today include high unemployment, limited private sector development, pervasive corruption, irresolute public and corporate governance dominated by a chosen elite, oversized public sector and low female labour participation. Improved living standards are required before political reform can be implemented and economic potential released (O'Sullivan et al., 2012).

\subsubsection{Palestinian Refugee Outcomes 1948 on}

In the 1950's and 1960's the refugee Palestinians challenged the monarchy, wishing to undo the 1948 war results; Palestinian militancy against Israel dragged Jordan into the disastrous Six Day War when Jordan lost the West Bank to Israel. This resulted in continuing territorial nationalism by the Palestinian Liberation Organization (PLO) who represented this movement mainly on the East Bank of the Jordan River and set up a threatening state within a state. In the "Black September" civil war of 1970-1 caused by this group, King Hussain defeated the armed units of the PLO but its challenge still remains today because $50 \%+$ of the East Bank population is Palestinian. To keep Jordan peaceful and free of the spillover effects of the first Palestinian Intifada resistance of unarmed violent rebellion 1987- 1991 in the Israeli-occupied Palestinian Territories of the West Bank, Hussain disengaged from the area in July 1988 (Pape and Feldman, 2010) and made a peace treaty with Israel in 1994. The latest UNHCR statistics omit 4.9 million Palestinians and record them as registered with the United Nations Relief and Works Agency in the Near East (UNWRA) but they still mainly inhabit Jordan (Jun 192013 , UNHCR, 2014).

\subsection{Refugees from Iraq 2003-2011}

The second wave of refugees came from Iraq. Half a million Iraquis fled over the Jordanian border from the Iraq 
War to set up safe businesses and find a peaceful life. They were welcomed for their introduced business expertise and resources.

\subsubsection{Past Economic History}

Economic crises in the 1980's led the IMF and World Bank to advise Jordan to reduce government spending by making neo-liberal reforms. These reforms hurt the East Bankers who have become resentful at losing government support and jobs; while privatizing state enterprises further helped and enriched Palestinian entrepreneurs. King Abdullah II today is impatient of the reactionary and recalcitrant East Bankers as he attempts economic reforms (Goldberg, 2013). At the time of the Intifada (Dec. 1987-1991), the Jordanian economy was confronted by virtual collapse, from which the country has never recovered. Politically, the monarchy depended for the kingdom's stability on a tradeoff with non-Palestine East Bankers who enjoyed most of the government jobs, salaries and considerations, controlling the security services and military. The affluent Palestinians, in turn, control Jordan's private sector. This has led to jealousy between the two groups (Susser, 2013). The death of the capable and politically astute King Hussein in 1999 was critical in Jordan as he was succeeded by the less experienced and able King Abdullah II, under whom the monarchy had lost popularity and prestige, but the Hashemite regime is still seen today as "the thing that holds [the country] all together." (Hamid \& Freer, 2011).

\subsubsection{Present Economic Situation}

The Jordanian King is now in control of the nation not because of any major economic changes or genuine political reform but by the lack of an option-by default. This reduces the King's greatest problem to acquiring aid to struggle through its economic troubles of deficits.

King Abdullah (1999) saw economic problems as paramount over political changes. He began liberal economic reforms, reduced subsidies and initiated privatization to increase public sector and government efficiency. Various corruption scandals together with these policies alienated people, particularly the Trans-Jordanians by benefiting Palestinians. Abdullah II had a vision of socio-economic reforms: Jordan First, National Agenda attempted half-hearted top-down reform (Choucair, 2006) leaving the population no option but to go to the streets. The reason for failure of reform lies with the ruling elite: "This decade- long process, initiated by the king, has been largely ignored by an ossified layer of elites seeking to protect their own interests" (Muasher, 2011). A sharp drop in economic growth occurred in Jordan with the Arab Spring, the average GDP growth in Jordan between 2000-2010 of 6\%, dropped in 2011 to $2.6 \%$ and $-3.2 \%$ in 2013 followed by a very slow recovery (IMF, Deutsche Bank [DB.] Research, Jan 2013). Tourism, 12\% of Jordanian GDP, halved in 2011 (UNCTAD, DB Research), foreign reserves plummeted as currencies weakened (IFS). European help came, IMF loans and help from oil rich Gulf Countries. Increased public spending forced by the uprising subsequently increased public debt in a country with an existing high public-debt-to GDP ratio. IMF (2012a) recorded Jordan with deficits of -5.5 in 2010 , almost $80 \%$ of GDP. Unemployment is close to $30 \%$ mainly among youth; three elements: the youth unemployment, an overlarge public sector and regional market rigidities block growth (Ahmed, Guillaume \& Fuceri, 2012). In 2010 public employment was a huge $42 \%$ of the total (Bteddini and Heidenhof (2012) and for business-friendliness for start-up and operation of a local firm there are problems of corruption, anti-competitiveness and uncertainty regarding regulation, with Jordan ranked 98 of about 185 (World Bank 2013 Doing Business report). Government subsidies of $5 \%$ in 2010 to 14\% in 2012 are inefficient and unaffordable and not benefiting the poorest (National Authorities, IMF 2012b). Political instability increased with the abolition of fuel subsidies reform in late 2012. Diversification and enhancement of trade intra-regionally would help prospects. Jordan trades with EU and US bilaterally. Regionally, gains could ensue from liberalizing services trade in finance, communication and logistics (Santi, Saoussen \& Shaw, 2012) as well as reducing trade barriers and inefficient procedures, and generally arranging closer ties with other emerging markets (Brazil, Russia, China and India) who provide 12\% of trade, and with liberalized investment rules, general living standards would improve (IMF, 2012a).

\subsubsection{Jordanian Arab Spring 2011}

The disunited elements of Jordanian opposition were initially encouraged to demand reforms in January 2011 by the revolutionary success of other Arab peoples who lost their "fear of government". Both unhappy East Bankers, Trans-Jordanians and chiefly Palestinian-supported Muslim Brotherhood And Islamic Action Front (AIF) asserted disaffection, pressuring for socio-economic reform. Specifically they wanted more "inclusion in economic and political life, better governance and strengthened civil liberties" (Masetti, Komer, Forster et al., 2013). Jordanians did not want regime change in their 2011 demonstrations by tribal leaders, leftists and Islamists, but they felt "the political status quo is untenable" (Barari \& Satkowski, 2012) and only wanted 
change and improvement. As a result there was little violence. The uprising lasted three months till March 24, 2011 repression and some concessions by the king (Winter, 2011). The monarch has charted state-society relations by depriving and deposing: "institutionalized opposition to its rule and relying on the distribution of benefits and privileges to create a cohesive support base and a security establishment loyal to the existing political order" (Choucair, 2006). So a system of state patron-client relations removed political reform from the forefront (Barari \& Satkowski, 2012).

Ghabra (2012) characterized the situation as:

Issues such as unemployment, corruption, democratization, the voting system, and social justice, along with the power of the monarch versus the power of the parliament, stand at the core of the present movement in Jordan. Jordan currently sits at the crossroads of a total system collapse or far- reaching reforms that could lead to a constitutional monarchy. Attempts to avoid major reforms will only exacerbate the situation (Ghabra).

Al-Rfou (2013) in Tafila province found trade, business and investment were clearly harmed by the marches, sit-ins and strikes and nation-wide inefficient subsidy plans, low trade diversification and high youth unemployment have continued (Masetti, Komer, \& Forster et al., 2013).

\subsubsection{Parliamentary Democracy Situation}

After the 1989 protests Hussein allowed a relatively fair parliamentary election, then in 1991 the king enjoyed a further rise in popularity by a pro-Iraq stand on the First Gulf War, when he suspended martial law (in effect since, 1957) and outlined a new means of political participation in the Kingdom in the National Charter 1991, allowing an opposition. However the pro-Iraq stand dried up American aid and unemployed Jordanians returned from the Gulf. These problems led to changed electoral laws to control the opposition, and re-elections. This allowed the king a compliant parliament to make peace with Israel in 1993. By 1993, domestic political reform and democracy fell victim to international peace needs and political power became centralized in a few hands: a rich elite (Mufti, 1999). Two decades later parliament is weak, dysfunctional and irrelevant and the relations between the state and society are seriously strained. Members want personal favors to relatives or constituencies. Voting district arrangements favor rural areas and disenfranchise cities.

\subsubsection{Syrian Civil War Refugees: Third Incursion 2010}

Meanwhile Syria's Arab Spring after March 2011 sank into a yet-continuing sectarian bloodbath which horrified Jordanians, accompanied by an ongoing grave humanitarian crisis. This conflict had forced 647,000 to flee to Jordan, Lebanon and Turkey (UNHCR, 2012). To date the refugee number is 728,500 (UNHCR 2014) and over 100000 Syrian lives have been lost. This third wave of refugees in 72 years poured over the Jordanian border after 2010. Over 400,000 Syrians are now finding refuge in peaceful Jordan, at the end of 2012. 303,707 were recorded as assisted by UNHCR in Jordan camps, seeking to escape war or brutal repression from all sides. Only the rich ones who brought their money to Jordan are concerned with buying houses, apartments and businesses and the subject of the study. So finally, King Abdullah II has to cope with social, political and economic reform demands internally ass well as avoid these threats to internal stability by providing for increasing numbers of Syrian refugees, before their heavy load on the Jordanian infrastructure becomes unmanageable (Susser, 2013).

\section{Method}

\subsection{Qualitative}

This study was designed to investigate the effect of the Syrian Spring uprising and how it affected the Jordanian economy, specifically through the changes in real estate rental or selling price changes as a result of rich Syrians moving to Jordan for personal and economic security over the two years after the protests and subsequent unrest began. To find facts and perceptions about the topic, to understand the "why" of the individual's ideas behind the issue and how the respondents related to the issue, it was determined to use qualitative methodology because of its flexibility. This tells the researcher how realtors make sense of their lives.

The means chosen were individual semi-structured interviews, observation and reflective field notes in line with grounded theory, which should provide rich, intense, inductive material (Marshall \& Rossman, 1998). The target audience was all the realtors in the most affected city of Irbid in the north (population 600000 ) the second largest city in Jordan after Amman, the capital located further south of Syria. See Map below in Figure 1 with Irbid as the most northerly city in Jordan and the second most populous, and its proximity to Syria. 


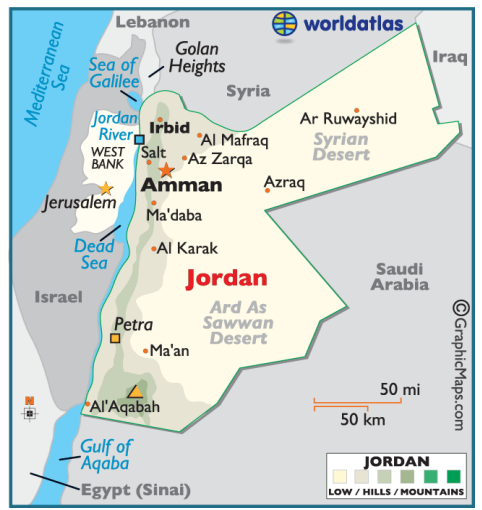

Figure 1. Location map of Irbid in Jordan, and Syria with surrounding nations

Source: World Atlas.

\subsubsection{Participants and Appropriateness of Methodology}

Thirty-three realtors in Irbid of the total of 41 existing were willing to discuss the situation, allowing a more interested and focused sampling. As a group the Jordanian realtors fell into the 28 to 55 age range, all males.

From initial informal conversations on their business with these co-operative realtors about being involved, it was possible to develop five open-ended questions on issues for semi-structured interviews to probe for further deeper, richer interview data based on the informal chats. They should allow the researcher to flexibly gather more in-depth data reflecting realtors' perceptions about accommodation and business competition as well as providing views of the surrounding socio-political and economic situation from the "common man", there being no women in a business which consists of a single entrepreneur and according to Jordanian mores. In-depth interviews were considered the best method for spontaneous individuals' perspectives and experiences, particularly in exploring sensitive political and economic topics easily recorded in field notes and adaptable for interaction with the researcher.

\subsubsection{Advantages of Methodology Design}

It allows understanding in depth about how people experience a business issue in a naturalistic setting, with the data based on each individual's personal categories of meaning-their values, opinions, belief systems and perspectives in a social context of local situations and economic conditions in context, which reveals political opinions and feelings about government from an insider's point of view All the data produces authentic findings about business which could not be determined in advance, using grounded theory.

\section{Results}

\subsection{Questions Discussed in Interviews}

The 33 subjects interviewed provided data in answer to the planned semi-structured individual interview questions, derived from initial informal contacts with those of the initial 41 targeted who agreed to participate. The five questions follow:

1). Will Jordanian Real estate business profits increase following the influx of Syrian refugees, both rich and poor?

2). Will commercial businesses gain from the refugee population influx?

3). Will the Jordanian lower socio-economic groups be further disadvantaged in the consumer and real estate marketplace?

4). Will the rise in accommodation costs and lack of availability caused by Syrian refugees cause further unrest among the poorer sections of the population?

5). Do you feel that discontent and unrest from higher living costs might cause King Abdullah II to give more political freedom and improve the economy by reform?

\subsubsection{The Data}

After collecting the raw data from interactions with the 33 respondents, some more forthcoming or opinionated than others, these field notes were coded into similar and different perceptions. The codes with key quotations 
were collated and analyzed creating the data following with perceptions subsequently summarized under each topic using comparison to give a reliable thematic analysis of underlying data (Saladana, 2012). Interpretation of qualitative analysis contains its core (Gifford, 1996)

The samples of quotations on issues are included for verisimilitude and clarity of results, followed by the summary.

\section{1) On the topic of the increase in business profits as a result of sales to Syrians}

Some quotations from interviews: "In 2012 I sold only five properties to Syrians ("Respondent [R] 7); "Most clients were Jordanians" (R 13); "Jordanian landlords increased their number of properties" (R21) Note: This apartment owner was a regular customer of R 21. "In 2011 I sold only 14 properties to Syrians [R 31]; "In 2011, I sold 12 shops, and 9 properties to Syrians" ( $R 15)$.

In 2011 our profit increased around 150\% compared to the year of $2010[R 16,31]$ We do not care about the nationality of the customers $(R 5,6,11)$. "I deal with whoever pays more rent, it does not matter, Jordanian or Syrian" (R 4)

\section{Coding summary}

Most of the responses were negative, because only approximately $10 \%$ of the realtor's total business was sales to Syrians from 2010-2013. The sales to rich Jordanians were predominant occurring for investment reasons because of the high demand by the Syrians for rental apartments, which were rising rapidly in price along with rental values, bringing large profits.

\section{2) On effects of the refugee influx on consumer business}

Quotations: "the bank's branches are very busy, because the banks have not expand their branches to accommodate the increasing number of people in Irbid City, or made other appropriate provision for increased business" [R31].

"About $10 \%$ of the refugees were buying their own big business in strategic places in the city and so they do a very good business there" [R13] "Around $20 \%$ of them rent existing business from Jordanians and according to their past experience in commerce they have improved these and therefore do better business" $[R$ 7]. "Irbid marketplace business is consequently growing rapidly" 1 : [R 11, R2, R15].

Summary: Most respondents said the marketplace was booming as a result of increasing numbers of refugees making purchases. Improved business occurred because the refugees in commerce who organised moving their wealth to Jordan were prosperous and experienced in business management.

Less affluent Syrian refugees receive help from International organizations and Gulf Countries, which encourages retail and consumer business, particularly food basics. However Jordanians are unhappy competing with richer refugees even if the national and local economy has gained overall, though further disadvantaging lower socio-economic Jordanian population group:

\section{3) Further disadvantaging of lower socio-economic Jordanian population group}

Quotations: "Dealing with Syrians such as renting apartments is easier, because they can pay three times more than Jordanians, with the money they receive from their relatives and international organizations indicated by crowded money exchange shops" [R 11]. Syrians seem to live very well on their better incomes" $[R$ 30] "This shortage of rentals leads Jordanians on limited incomes with no supplements to feel very resentful" [R 5]

"The Syrian boost to the national economy has increased productivity since 2011 compared to nowadays" $[R$ 27]; $1:[R$ 4, R15]

Summary-Rich: Two types of Jordanians already existed, a minority of very rich and the majority who were poor.

The few rich people, part of the elite, who had invested their money in commerce or real estate made an increased profit in the booming market resulting from increased consumers in Irbid City, and the continuing demand for accommodation drove up prices of their properties and rents (comments R30, R 5 above]

Quotations: "The majority of limited income people became worse off than before because they could no longer rent even a small apartment. This was particularly hard on the younger people just starting out. Those already or newly married were forced into divorce because they could not pay the increased rent comparing what they could afford to rentals offered by richer Syrians" [1: R 4, R5, 6, 11; 2 C: R 11].

Summary-Limited income. The majority of limited fixed income Jordanians were displaced and restive, leading 
to strong local unrest and overcrowding in family accommodation, and such discontent is still going on in society.

Quotations on Government policies: "This problem happened because the government did not make a Strategic plan to accommodate this situation of housing when they hospitably opened the country border to the huge number of refugees" $[R 21]$ "Many not in camps, perhaps 50\% of them coming to Irbid are very wealthy and the rest are receiving money amounting to maybe 3-4 times more than the regular and limited Jordanian income" $[R$ $4, R 2, R$ 15]. "The government could not close the border for political reasons, we must accept the situation" [R 22].

Summary: Situational acceptance, need for offering hospitality and general fatalism seem to pervade the overall feelings and responses, with little resentment against the government.

4) Possibility of discontent and unrest from higher living and accommodation costs giving impetus to socio-political and economic reform demands

Quotations: "Jordan is a very peaceful country and that political circumstances in the north of the country do not allow the type of widespread uprising because of the very strong security system in Jordan and a very clever King"' $R$ 30]. "Most of the Jordanians love the king very much, because their commercial activity in Irbid has continued to increase [R 28].

"Our history of peace and recent good relations with EEC and USA and Arab nations should protect the nation politically and commercially $[R$ 13], "The King has a very open mind and he has very good relationships with most overseas countries" [R 16].

"Because of our stability and security more foreigners have invested locally in the past few years according to the business news" [R 4] ] "Al Hassen Industrial Zone in Irbid city demonstrates the attractiveness of Irbid for investment" [R 3].

Summary: These opinions indicated goodwill towards the monarchy, and realtor appreciation for profitable local economic conditions and did not indicate any possibility of public unrest leading to local demands for change as in 2011 in the south.

\section{5) On the possibility of real estate prices rising, or stabilizing and the effects}

Quotations: "The prices will increase again because the war in Syria is not stopping soon and the refugee influx continuing will support demand" [R 33].

"They must stay the same if the price increased again, it would lead to anti-social actions by deprived or poor Jordanian citizens. For example an increase in the rate of theft and more police arrests, possible riots" [R 3] " $A$ country like Jordan led by a clever King, cannot stop watching this situation and do nothing, for there the government will plan to resolve this problem for the prices will remain stable. He may increase the salary for the people of limited income to accommodate the prices increase which happened since 2011, or encourage poor and but qualified people to establish small enterprises to help them live well" [R 30].

When most of refugees returned to Syria it would remove the upward pressure on the market and leave vacant apartments and houses" [R 11].

Summary: Increase seemed most likely with war continuing and fears were expressed for the displaced Jordanians and crime rise; only war's end would decrease prices. Also expressed was a faith in the King and a hope for the war to end to improve the present situation.

\section{6) The discussion about future real estate prices and the effects:}

Quotations: "Low-income Jordanians would demand salary increases by those employed by the government (totalling $42 \%$ of the population:- researcher) to maintain a decent (or their former) standard of living" [R .3] "If these increased prices are not provided for or compensated by some government action, there will be further widespread social unrest among the lower socio-economic groups as well as government employees, typical of what led to the Arab Spring uprisings elsewhere" [R. 20) "The Syrian civil war created great hardship for limited income Jordanians so the government should take action to resolve the living standard gap to avoid another 2011" [R 9].

Summary: Social unrest from rising real estate prices and living costs fuel general social unrest, putting pressure on the government for action.

\section{Discussion}

For the original five questions under discussion the focus of this qualitative research process showed how 
participants experienced and perceived the consequences of the Syrian civil war refugees on their lives, jobs and business and how they made sense of their lives in their world as realtors in Irbid.

\subsection{Available Qualitative Evidence}

To relate the separate perceptions and opinions of the 33 businessmen with hard data, figures were obtained from Government Departments on sales and rentals officially recorded. The table below, Figure 2, shows $2010-$ 2013, figures obtained in 2014 from the Government Land Centre and Land Department. These demonstrate the real estate profits increase 2010-2013.

Table 1. Irbid Accommodation purchases and rental numbers 2010-2013

\begin{tabular}{llccccc}
\hline Year & 2010 Pre-Arab Spring & 2011 & 2012 & 2013 & $\begin{array}{l}\text { Total } \% \text { increase since } \\
2010\end{array}$ \\
\hline $\begin{array}{l}\text { Apartments and houses } \\
\text { sold }\end{array}$ & 797 & 827 & 1441 & 1713 & $115 \%$ & \\
\begin{tabular}{l} 
Rentals completed \\
\hline
\end{tabular} & 2121 & 3096 & 4211 & 5865 & $177 \%$ & \\
\hline
\end{tabular}

Source: Government Land Centre and Govt. Land Department (Irbid). 2014.

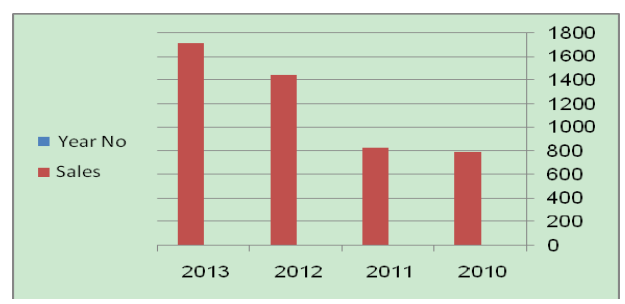

Figure 2. Increase in numbers of apartment and houses Sales 2010-2013

Source: Government Land Centre and Govt. Land Department (of Irbid). 2014

Table 2. Yearly percentage Increases in Irbid purchases and rentals since 2010

\begin{tabular}{lcccc}
\hline \multicolumn{1}{c}{ Year } & 2010 Pre-Arab Spring & 2011 & 2012 & 2013 \\
\hline $\begin{array}{l}\% \text { Sales increase on previous year in } \\
\text { houses \& apartments }\end{array}$ & - & $5 \%$ & $74 \%$ & $19 \%$ \\
$\begin{array}{l}\text { \% Sales increase on previous year in } \\
\text { houses \& apartments }\end{array}$ & - & $46 \%$ & $36 \%$ & $39 \%$ \\
\hline
\end{tabular}

Source: Government Land Centre and Govt. Land Department (of Irbid).

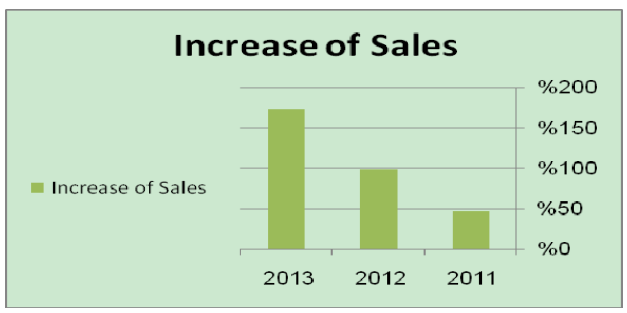

Figure 3. Percent of sales increase in houses 2010-2013

Source: Government Land Centre and Govt. Land Department (of Irbid). 2014

\subsubsection{Business Profits and Syrian Purchasers}

The increases in both sales and rentals recorded in Tables $2-4$ above graphically demonstrate the first question was correct in assuming that sales continued to rise, particularly in 2012; while rental increases were steady and high after an initial impetus. However the reason for increased profits was not necessarily Syrian purchasers 
(estimated at only 10\%) but rich Jordanians who could afford to invest in real estate. This means rather that $90 \%$ of purchasers were fellow rich Jordanians (the "elite") buying apartments and houses who were exploiting the lower socio-economic quartile not the few Syrians, as initially expected by the researcher. Therefore the already rich became richer while the poor dropped in the socio-economic scale exacerbating existing social instability.

\subsection{Gain by Commercial Businesses from Refugee Population}

More purchasers particularly for food and domestic commodities would come from an increased population of refugees providing more competition in the marketplace, driving up prices and increasing poverty of fixed income Jordanians, thus widening the gap between rich and poor. Further disadvantaging of lower socio-economic Jordanian segment. While the rich Jordanians prospered to the cost of the majority, these people lost ground socio-economically, with the young most affected, forced to live at home causing overcrowding and increasing social disaffection.

\subsection{Increased Unrest/Discontent of Lower Socio-Economic Groups Giving Impetus to Socio-Political and Economic Reform}

While rich Jordanian investors profited from the increased prices and rental demand, the hardship of poorer Jordanians increased while they vainly sought or lost accommodation. This is continuing to cause social and economic unrest, when Syrians can afford to pay more and so drive up prices. However the majority of realtor interviewees were proud of Jordan which they perceived as a peaceful country with a strong security system to control unrest. They felt King Abdullah II maintains good relationships with the rest of the world, particularly USA. They are strongly loyal to the King because business activity is flourishing for realtors and should continue this way. Foreign investment was perceived to have recently increased because of Jordan's stability and economic attractiveness.

\subsection{Fluctuations in Real Estate}

A. Two main realtor opinions emerged on further rises: first, continued refugee influx will increase demand; second, stability was necessary to avoid making the situation of the deprived in Irbid worse for the authorities to cope with. A few realtors believe prices will fall when refugees return to rebuild their lives in Syria post war.

B. The majority of Jordanians missing out on accommodation, these of lower income in government employment ( $42 \%$ of the population) are demanding salary increases to retain their former standard of living. Those not in government employment also need better wages for a decent living standard. Collectively these demands require action by authorities to avoid further growing unrest; but can the indebted nation afford these pressures?

\subsection{Limitations of Study}

Like all qualitative research, these interpretations are based on a limited amount of input from businessmen, thus is not necessarily empirically valid, nor applying outside Irbid. However this data gives an insight into the way political attitudes are formed by one business population segment. Given these unique findings, the knowledge recorded here will not necessarily generalize to other people or settings in Jordan.

The research time to collect and analyses data might be outweighed by the limited value of the results gathered and by its transferability for reliability, given the subjectivity of observations, and interpretations may be determined or influenced by the individual bias and idiosyncrasies of the researcher. But, according to Guba (1981) dependability of results can be determined beyond the study by how similar it is to similar situations and how well it matches another context or city with a refugee population outside the study situation (Anderson \& Taylor, 2009; Guba, 1981).

\subsection{Conclusions}

Jordan has given a peaceful reception to three large groups of refugees. One result for a poor country is to increase economic problems for businesses. Only the improvement of living standards by better administration, removal of corruption, stimulating private sector growth, trade enhancement and foreign investment will create entrepreneurial industries and increased employment and possibly a reduction of the bloated public sector. Such developments would permit increased political freedom and inclusion in the political process, and improved economic conditions: aspirations of the 2011 demonstrators and promises at that time by King Abdullah. Increased Syrian demand on the Irbid accommodation market resulted in purchases which mainly further enriched the wealthy Jordanian elite. They have historically blocked economic reforms and supported corruption from their entrenched position in the administration. This accommodation demand increased their riches; since only $10 \%$ of profiting purchasers were Syrian. Syrian capital and business expertise helped improve Jordan's 
economy from the small rich refugee proportion not settled, like the poorer majority, in huge camps on the border. The majority of lower income Jordanians suffered from rising house prices and increased cost of living with the booming consumer market, and though they could potentially demonstrate, some Jordanians demand only increased government salaries to cope. The king is popular and seen as doing his best to boost Jordanian business and economy.

\section{References}

Al-Rfou, A. N. (2013). The Impact of Jordan Spring on Business and Investment Activities from Respondents' Perspective. Interdisciplinary Journal of Contempary Research in Business, 4(12), 1256-1263.

Anderson, M. L., \& Taylor, H. F. (2009). Sociology: The Essentials. Belmont, CA: Thomson Wadsworth.

Barari, H. A., \& Satkowski, C. A. (n.d.). The Arab Spring: The Case of Jordan. Ortadogu Etütleri, 3(2), 41-57.

BBC News. (2011). Jordan protests: King Abdullah names Marouf. Retrieved from http://www.bbc.co.uk/news/world-middle-east-12336960

Center for Strategic Studies. (2012). The performance of the Jordanian economy in light of the Arab Spring. University of Jordan, Amman.

Choucair, J. (2006). Illusive Reform: Jordan's Stubborn Stability. Carnegie Papers.

Denzin, N., \& Lincoln, Y. (2011). Sage Handbook of Qualitative Research (4th ed.). Thousand Oaks, CA: Sage.

Fisk, R. (2010). Why Jordan is occupied by Palestinians.

Gifford, S. (1996). Qualitative Research: The Soft Option? Health Promotion Journal of Australia, 6(1), 58-61

Goldberg, J. (2013). Monarch in the Middle. The Atlantic.

Guardian. (2014). Aid to Syria: the 5 Big Questions. Retrieved from http://www.theguardian.com/news/datablog/2014/jan/15/aid-to-syria-the-5-big-questions

Guba, E. G. (1981). Criteria for assessing the trustworthiness of naturalistic inquiries. Educational Resources Information Centre Annual Review Paper, 29, 75-91.

Hamid, S., \& Freer, C. (2011). How Stable is Jordan? Abdullah's Half-hearted Reforms and the Challenge of the Arab Spring. Brookings Doha Center, Policy Briefing.

International Monetary Fund. (2012a). Regional Economic Outlook Update: Middle East and North Africa: Historic Transitions under Strain.

International Monetary Fund. (2012b). Regional Economic Outlook: Middle East and Central Asia.

Khandelwal, P., \& Roitman, A. (2013). The Economics of Political Transitions: Implications for the Arab Spring. IMF Working Paper.

Malik, M. (1999). Elite Bargains and the Onset of Political Liberalization in Jordan. Comparative Political Studies, 32(1), 100-129.

Marshall, C., \& Rossman, G. B. (1998). Designing Qualitative Research. Thousand Oaks, CA: Sage.

Masetti, O., Komer, K., Forster, M., \& Friedman, J. (2013). Two years of Arab Spring. Deutche Bank Research, $1-14$.

Muasher, M. (2011). Decade of Struggling Reform Efforts in Jordan: The Resilience of the Rentier System. Carnegie Endowment For International Peace.

Nichols, C. (2011). Strengths and Weaknesses of Qualitative Research. Alexander Technique College. Retrieved from http://www.alexander-technique-college.com/files/2011/10/books_articles_qualitative.pdf

O'Sullivan, A., Rey, M. E., \& Mendez, J. G. (2012). Opportunities and Challenges in the MENA Region. World Economic Forum Middle East, MENA-OECD Economics Dept. \& Investment Program Report.

Paper, R. A., \& Feldman, J. K. (2010). Cutting the Fuse: The Explosion of Global Suicide Terrorism and How to Stop It. Chicago: University of Chicago Press.

Saladana, J. (2012). The coding manual for qualitative researchers. Thousand Oaks, CA: Sage.

Susser, A. (2013). Jordan and the Faltering Fortunes of the Arab Spring. Update of Middle East Developments. Moshe Dayan Center at Tel Aviv University.

UNHCR. (2012). Statistics on Refugees. Retrieved 
http://www.theguardian.com/news/datablog/2013/jun/19/refugees-unhcr-statistics-data

Winter, L. (2013). Jordan and Saudi Arabia after the Arab Spring. Foreign Military Studies Office, Dept. of Defence, USA.

World Bank and International Finance Corporation. (2013). Doing Business 2013: Smarter Regulations for Small and Medium-Size Enterprises.

\section{Copyrights}

Copyright for this article is retained by the author(s), with first publication rights granted to the journal.

This is an open-access article distributed under the terms and conditions of the Creative Commons Attribution license (http://creativecommons.org/licenses/by/3.0/). 
International Journal of Business and Management; Vol. 9, No. 6; 2014

ISSN 1833-3850 E-ISSN 1833-8119

Published by Canadian Center of Science and Education 